\title{
Enhancing biogas quality of indigofera plant waste through co- digestion with cow dung
}

\author{
Finda Sihta $^{a, *}$, Suyitno ${ }^{b}$, Atmanto Heru Wibowo $^{c}$, and Retno Tanding ${ }^{d}$ \\ ${ }^{a}$ Chemistry Department, Institut Pertanian Bogor, Jl. Raya Dramaga, Bogor, Indonesia \\ ${ }^{b}$ Mechanical Engineering Department, Universitas Sebelas Maret, Jl. Ir. Sutami 36 A, Surakarta, Indonesia \\ ${ }^{c}$ Chemisty Department, Universitas Sebelas Maret, Jl. Ir. Sutami 36 A, Surakarta, Indonesia \\ ${ }^{\mathrm{d} E}$ Economic and Business Faculty, Universitas Sebelas Maret, Jl. Ir. Sutami 36 A, Surakarta, Indonesia
}

\begin{abstract}
The production process of indigofera plants yields $10 \%$ of blue natural dyes and wastes are $90 \%$. The biomass wastes from the extraction of indigofera plants are classified as difficult to process in an Anaerobic Digester (AD) because of the large content of hemicellulose in the Indigofera stems. Therefore, the study reports the anaerobic digestion of Indigofera plant wastes co-digested with cow dung for enhancing the biogas quality. The digestion process was conducted in a vessel of $160 \mathrm{~L}$ with various weight ratios between Indigofera biomass and cow dung by $0 \%, 25 \%, 50 \%, 75 \%$, and $100 \%$. The results show that the AD reactor temperature kept above $29.5^{\circ} \mathrm{C}$ with a $\mathrm{pH}$ between $6-7$ were the key factors for enhancing the biogas quality. The co-digestion between $50 \%$ indigofera wastes with $50 \%$ cow dung yielded biogas with a $\mathrm{CH} 4$ content of about $42 \%$ and $\mathrm{H} 2 \mathrm{~S}$ concentration below $40 \mathrm{ppm}$ showing that the biogas has the potential to be further improved in quality and can be used to fuel the stove and power generation.
\end{abstract}

\section{Introduction}

Anaerobic digestion (AD) is an old technology which gains a renewed interest, especially in a new route for the process of biomass wastes into biogas. Raw materials commonly digested into biogas are cow dung, chicken manure, pig manure, palm oil mill effluent (POME), and sugar cane processing wastes. In the AD process, the quality of biogas produced is influenced by biological oxygen demand (BOD), chemical oxygen demand (COD), and total suspended solid (TSS) from raw materials. BOD, COD, and TSS of POME are about 10 $\mathrm{g} / \mathrm{L}$ and $50 \mathrm{~g} / \mathrm{L}$, and $31 \mathrm{~g} / \mathrm{L}$ respectively [6], with $\mathrm{pH}$ between 4 and 5 . The methane yield of co-digestion between POME and empty fruit bunches (EFB) was 276$340 \mathrm{~L} / \mathrm{kg}$ [11]. Meanwhile, BOD, COD, and $\mathrm{pH}$ of sugar cane processing wastes were $0.8-2.5 \mathrm{~g} / \mathrm{L}, 1.6-6.8 \mathrm{~g} / \mathrm{L}$, and $10.2[13,4]$. The methane yield of $72.1 \mathrm{~L} / \mathrm{kg}$ was achieved with peroxide pretreatment digestion of bagasse [14]. It can be seen that BOD and COD strongly affected the composition and quality of biogas. Raw materials with low COD indicate the small amount of organic material that can be processed into biogas. Low COD also shows that during the $\mathrm{AD}$ process, bacteria will consume more acid.

Besides BOD, COD, and TSS, the following factors that affect to the composition and quality of biogas are the $\mathrm{C} / \mathrm{N}$ ratio, $\mathrm{pH}$, and digester temperature. In addition, agricultural wastes are generally rich in $\mathrm{C}$ content, but deficiency $\mathrm{N}$ with a ratio close to 200 [17]. In contrast, farm wastes are rich in $\mathrm{N}$ content, but lack of $\mathrm{C}$ [16], with the ratio ranging from 8 to 50 . Ideal $\mathrm{C} / \mathrm{N}$ ratio for $\mathrm{AD}$ is 30. Moreover, $\mathrm{pH}$ of agricultural and farm wastes is generally ranging from 5 to 7 . The ideal $\mathrm{pH}$ is between 6,5 and 7,6 [15], with the ideal temperature for meshophilic bacteria is between 35 and $40^{\circ} \mathrm{C}$ [17], for the best growth of fermenter bacteria in $\mathrm{AD}$.

$\mathrm{AD}$ is a complex process that is affected by many variables. Every raw material has a unique character, thus requiring different treatment. To the best of our knowledge, there is no report about $\mathrm{AD}$ with indigofera plant wastes from the extraction process of blue natural dyes. This success is important from practical point of view, because the amount of wastes in the extraction process of blue natural dyes can reach $90 \%$ by weight. Unfortunately, the most indigofera wastes are stems containing much hemicellulose and lignocellulose. The subtrates with high content of cellulose and lignin that interlink each other [10], becomes difficult to hydrolyze, so that the yield of biogas is low. To overcome this, some researchers have proposed some pretreatment processes before processing in $\mathrm{AD}$, such as thermo-chemical [12], thermal $[2,1]$, mechanical-chemical-enzymatic [3], alkaline [7], and biological [9] pretreatments. The methods are successful for enhancing the yield of biogas, but the pretreatment processes are less practical, as they require additional equipment and also sometimes use additional chemicals that may add an operational cost.

Therefore, this study aims to enhance the quality of biogas from wastes of indigofera biomass that is codigested with cow dung. Various variables such as 
temperature and $\mathrm{pH}$ were observed real time in the $\mathrm{AD}$ placed above the ground.

\section{Methods}

Raw materials used were the waste of biomass from the extraction process of blue natural dyes, indigofera tinctoria. The main wastes contain substantial amount of stems but less amount of leaves. Another substrate used was cow dung. The bacteria that used in $\mathrm{AD}$ were the EM4 (effective microorganism).

There were two AD reactors with size of $160 \mathrm{~L}$ each. The first reactor was filled the substrate with a ratio of $17.5: 17.5: 35 \mathrm{~kg}$ and the second was with a ratio of 35:35:70 kg. Therefore, it could be observed the influence of the number of packing in the $\mathrm{AD}$ reactor. The $\mathrm{AD}$ reactor schematic can be seen in Figure 1. To investigate the effect of co-digestion, the indigo content in substrate was varied at $100 \%, 75 \%, 50 \%, 25 \%$, and $0 \%$.

Before feeding into the AD reactor, indigofera wastes were mechanically sliced to produce small pieces of biomass thickness of $\pm 1 \mathrm{~cm}$. Then the results of sliced biomass were mixed with cow dung and water in accordance with its predetermined ratio. The amount of biogas produced, the temperature of the reactor, and the $\mathrm{pH}$ of AD were measured periodically. $\mathrm{CH}_{4}$ and $\mathrm{H}_{2} \mathrm{~S}$ contents in biogas were measured daily and taken the average.

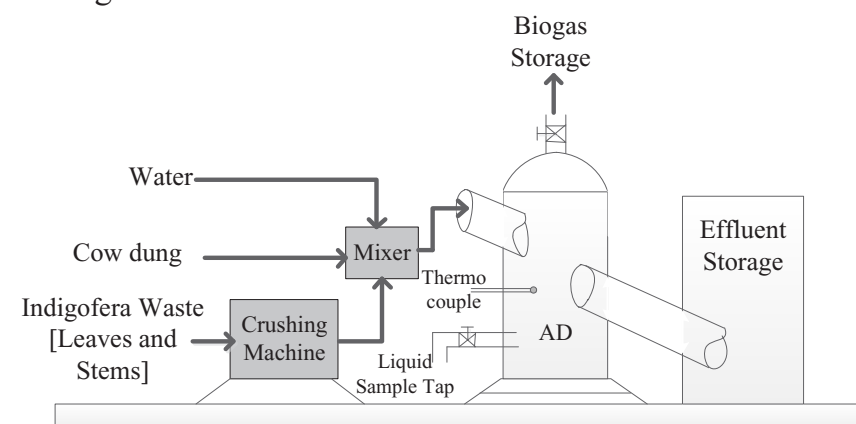

Fig. 1. Scheme of $\mathrm{AD}$ reactor

\section{Results and Discussion}

Figure 2 shows biogas output and temperature of the first and second $\mathrm{AD}$ reactor. It appears that the reactor temperature fluctuated and was influenced by the surrounding. The AD reactor was made of high-density polyethylene (HDPE) without insulation and placed on the ground in order the effect of the environmental temperature on $\mathrm{AD}$ reactor can be studied. The weather variable influencing to the temperature of $\mathrm{AD}$ was the rainy conditions especially at night and occurred on several days (days 12 to 15 ). When the rain occurred at night, the temperature of the reactor dropped dramatically even below $27^{\circ} \mathrm{C}$. When the rain occurred during the day with medium intensity during 2-4 hours, the reactor temperature has decreased slightly but still able to stay above $29^{\circ} \mathrm{C}$.

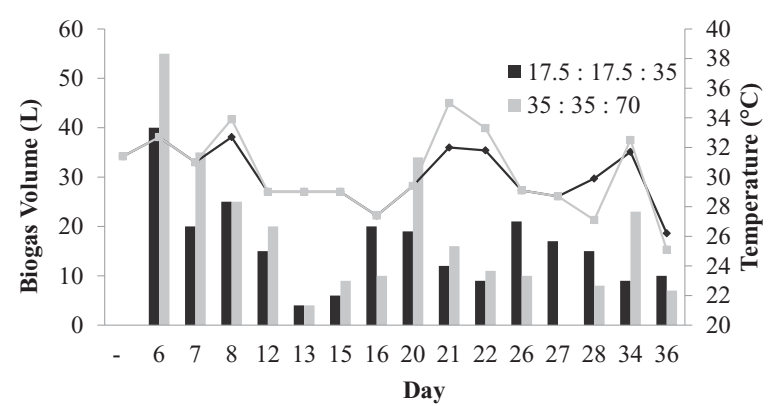

Fig. 2. Biogas yield and $\mathrm{AD}$ temperature.

The dramatically decrease of the AD temperature was also followed by a decrease of $\mathrm{pH}$ in the $\mathrm{AD}$ reactor as can be seen in Fig. 3 The condition of acidity in the first $\mathrm{AD}$ reactor is more sensitive to the effect of temperature than the second AD reactor. The response of increasing $\mathrm{pH}$ with an increase in temperature of $\mathrm{AD}$ was slow. This indicates that at low temperatures, anaerobic digestion conditions undergo acidogenesis.

It has been widely expressed by previous researchers that temperature is an important parameter for microorganisms to grow based on optimum requirements and to increase biogas production. Ranging temperature is an important technique for distinguishing the digestive process. There are three types of operation that can be used in anaerobic digesters: psychophilia $\left(25^{\circ} \mathrm{C}\right)$, meshophilic (about $35^{\circ} \mathrm{C}$ ) and thermophilic (about $55^{\circ} \mathrm{C}$ ). Optimum growth of microorganism is in meshophilic and thermophilic temperature. AD microorganisms are very sensitive to temperature changing that affect the production of hydrogen and methane, and decomposition of organic matter [5]. Low temperatures cause the low production of volatile fatty acids (VFA) from lignocellulose thereby decreasing the production of biogas. In general, the $\mathrm{pH}$ in $\mathrm{AD}$ reactor of the codigestion between indigofera biomass waste and cow dung was 6.54 and 6.32 at first and second reactor, respectively.

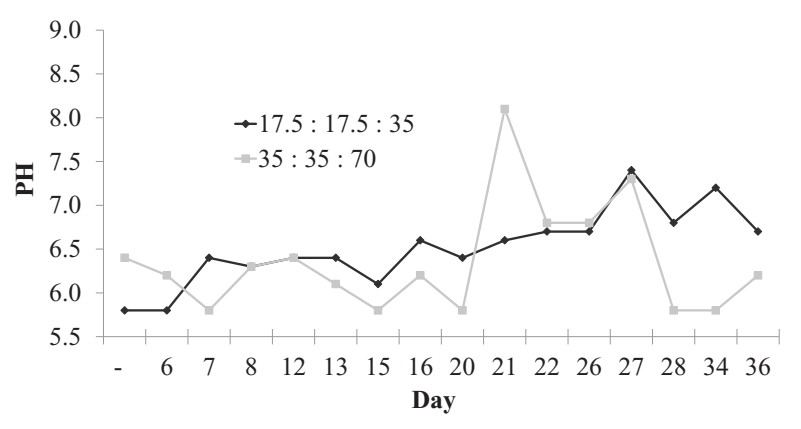

Fig. 3. $\mathrm{pH}$ conditions in $\mathrm{AD}$ reactor.

The $\mathrm{pH}$ conditions and temperature of the $\mathrm{AD}$ reactor were very influential on the yield of biogas. At temperatures higher than $29.5^{\circ} \mathrm{C}$ with a $\mathrm{pH}$ of about 6 to 7 , biogas can be produced in large quantities. At temperatures less than $29.5^{\circ} \mathrm{C}$ the digestion reaction tends to be slow. The $\mathrm{pH}$ level at 6.0 causes the highest hydrolytic enzyme activity and therefore the content of VFA is also high. Methanogenesis is most efficient at $\mathrm{pH}$ $6.5-8.2$, and the optimum $\mathrm{pH}$ is 7.0 at the common 
substrates. In the $\mathrm{AD}$ process, methanogenesis microorganisms are very sensitive to $\mathrm{pH}$ variations and prefer a $\mathrm{pH}$ around 7.0. Acidogenesis microorganisms are relatively less sensitive to $\mathrm{pH}$ and are tolerable to the range of 4.0-8.5. However, the optimum $\mathrm{pH}$ for hydrolysis and acidogenesis is between 5.5 and 6.5 (Mao et al., 2015)

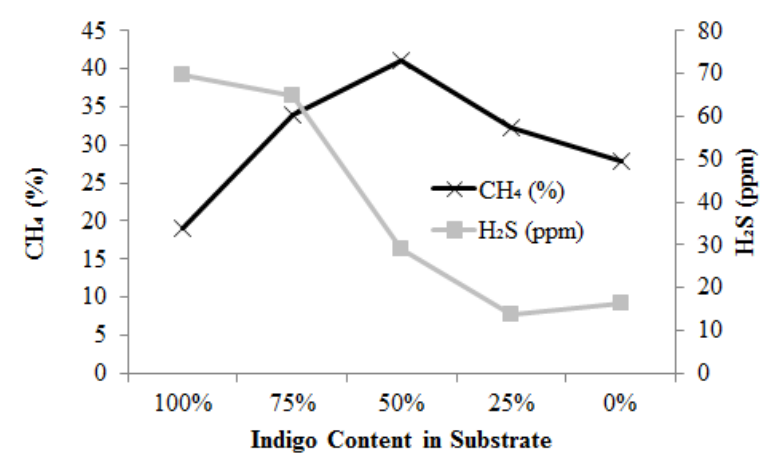

Fig. 4. $\mathrm{CH}_{4}$ and $\mathrm{H}_{2} \mathrm{~S}$ content from $\mathrm{AD}$ reactor with various content of indigofera in substrate

In the $\mathrm{AD}$ process with $100 \%$ indigofera, the biogas produces only contains $19 \%$ of $\mathrm{CH}_{4}$ making it very difficult to burn. Addition cow dung up to $50 \%$ while maintaining a mass ratio of 1:1 between water and substrate can significantly increase the content of $\mathrm{CH}_{4}$ about $42 \%$ as can be seen in Figure 4. Although still low, the biogas containing with $42 \%$ of $\mathrm{CH}_{4}$ can be easily burned. Meanwhile, the concentration of $\mathrm{H}_{2} \mathrm{~S}$ is below 40 $\mathrm{ppm}$. The addition of cow dung could improve the process of methanogenesis because could increase the $\mathrm{C} / \mathrm{N}$ ratio of indigofera wastes from 21.

\section{Conclusions}

The study has successfully demonstrated the co-digestion process between wastes of indigofera plant and cow dung. It is very important to keep the $\mathrm{AD}$ reactor temperature above $29.5^{\circ} \mathrm{C}$ with a $\mathrm{pH}$ between 6 and 7 . With a $\mathrm{CH}_{4}$ content of about $42 \%$ and $\mathrm{H}_{2} \mathrm{~S}$ concentration below 40 ppm, the biogas produced by co-digestion between indigofera wastes and cow dung has the potential to be further improved in quality and can be used to fuel the stove and internal combustion engine.

This work is fully supported by the grant of INSINAS from the Ministry of Research, Technology, and Higher Education, the Republic of Indonesia with contract number 453/UN27.21/LT/2016 FY 2016 and 2017.

\section{References}

1. Cuetos, M. J., Gómez, X., Otero, M. and Morán, A. (2010). Anaerobic digestion and co-digestion of slaughterhouse waste (SHW): Influence of heat and pressure pre-treatment in biogas yield. Waste Management, 30(10), 1780-9.

2. Ferrer, I., Ponsá, S., Vázquez, F. and Font, X. (2008). Increasing biogas production by thermal $\left(70^{\circ} \mathrm{C}\right)$ sludge pre-treatment prior to thermophilic anaerobic digestion. Biochemical Engineering Journal, 42(2), 186-92.

3. Frigon, J.-C., Mehta, P. and Guiot, S. R. (2012). Impact of mechanical, chemical and enzymatic pretreatments on the methane yield from the anaerobic digestion of switchgrass. Biomass and Bioenergy, $36(1-11$.

4. Ghodale, M. D. and Kankal, S. B. (2014). Investigation of optimum operating parameters for BOD \& COD removal using activated carbon. International Journal of Recent Development in Engineering and Technology, 2(4).

5. Hagos, K., Zong, J., Li, D., Liu, C. and Lu, X. Anaerobic co-digestion process for biogas production: Progress, challenges and perspectives. Renewable and Sustainable Energy Reviews.

6. Ibrahim, A. H., Dahlan, I., Adlan, M. N. and Dasti, A. F. (2012). Comparative study on characterization of Malaysian palm oil mill effluent. Research Journal of Chemical Sciences, 2(12).

7. Liew, L. N., Shi, J. and Li, Y. (2011). Enhancing the solid-state anaerobic digestion of fallen leaves through simultaneous alkaline treatment. Bioresource Technology, 102(19), 8828-34.

8. Mao, C., Feng, Y., Wang, X. and Ren, G. (2015). Review on research achievements of biogas from anaerobic digestion. Renewable and Sustainable Energy Reviews, 45(540-55.

9. Müller, H. W. and Trösch, W. (1986). Screening of white-rot fungi for biological pretreatment of wheat straw for biogas production. Applied Microbiology and Biotechnology, 24(2), 180-5.

10. Noike, T., Endo, G., Chang, J. E., Yaguchi, J. and Matsumoto, J. (1985). Characteristics of carbohydrate degradation and the rate-limiting step in anaerobic digestion. Biotechnol Bioeng, 27(10), 1482-9.

11. O-Thong, S., Boe, K. and Angelidaki, I. (2012). Thermophilic anaerobic co-digestion of oil palm empty fruit bunches with palm oil mill effluent for efficient biogas production. Applied Energy, 93(64854.

12. Penaud, V., Delgenes, J. and Moletta, R. (1999). Thermo-chemical pretreatment of a microbial biomass: influence of sodium hydroxide addition on solubilization and anaerobic biodegradability. Enzyme and microbial technology, 25(3), 258-63.

13. Prasad, D. Y. (1991). Biogas generation from bagasse-based paper mills by anaerobic digestion. Journal of Chemical Technology \& Biotechnology, 51(4), 515-24.

14. Rabelo, S. C., Carrere, H., Maciel Filho, R. and Costa, A. C. (2011). Production of bioethanol, methane and heat from sugarcane bagasse in a biorefinery concept. Bioresource Technology, 102(17), 7887-95.

15. Rittmann, B. E. and McCarty, P. L. (2001), Environmental biotechnology: Principles and 
applications, McGraw-Hill.

16. Saputra, T., Triatmojo, S. and Pertiwiningrum, A. (2010). Produksi biogas dari campuran feses sapi dan ampas tebu (bagasse) dengan rasio $\mathrm{C} / \mathrm{N}$ yang berbeda. Buletin Peternakan, 34(2).

17. Shuler, M. L. and Kargi, F. (2001), Bioprocess engineering: Basic concepts, Prentice Hall. 